Mycobacterium abscessus is a non-tuberculous mycobacterium which is found widely in soil and water. It is mostly known to cause infection in immunocompromised patients or those with an underlying lung disease, but infection is increasingly seen in otherwise healthy patients. It is commonly multi-drug resistant and presents a challenge for eradication.

This case highlights the presentation of a previously well 2 month old with pulmonary Mycobacterium Abscessus infection. Initial treatment involved a prolonged course of antibiotics. At 9 months of age, whilst still on treatment, the patient presented with a swelling in the right axilla, which was shown to be osteomyelitis of the 6th rib, with cold abscess formation. He was managed with surgical debridement and antibiotics. The patient was also given interferon following the immunological testing. This identified a heterozygous IL-12 gene variant and reduced production of interferon-gamma to all stimuli.

\section{G382(P) ABSTRACT WITHDRAWN}

\section{G383(P) 8 HIGH IMPACT INTERVENTIONS: A REGIONAL SURVEY OF TRAINEE EXPERIENCE}

${ }^{1} \mathrm{D}$ Aguirre, ${ }^{2} \mathrm{~S}$ Steadman, ${ }^{3} \mathrm{M}$ O'Keeffe, ${ }^{3} \mathrm{D}$ Kenyon-Blair, ${ }^{4} \mathrm{H}$ Cooper, ${ }^{5} \mathrm{R}$ Negrine, ${ }^{6} \mathrm{H}$ Goodyear, Paediatric Research Across the Midlands Network. ${ }^{1}$ Neonates, University Hospitals Birmingham NHS FT, Birmingham, UK; ${ }^{2}$ Community Paediatrics, Birmingham Community Healthcare NHS FT, Birmingham, UK; ${ }^{3}$ Community Paediatrics, Coventry and Warwickshire Partnership NHS Trust, Coventry, UK; ${ }^{4}$ General Paediatrics, Worcestershire Acute Hospitals NHS Trust, Worcester, UK; ${ }^{5}$ Neonates, Royal Wolverhampton NHS Trust, Wolverhampton, UK; ${ }^{6}$ General Paediatrics, University Hospitals Birmingham NHS FT, Birmingham, UK

\subsection{6/archdischild-2020-rcpch.327}

Aims To explore local trainees' experience, identify emerging themes, good practice examples and make key regional recommendations.

Method A voluntary questionnaire was designed based on the ' 8 High Impact Actions to Improve the Working Environment for Junior Doctors' document by NHS Improvement. This was circulated on paper at trainees' regional teaching days and online via Survey Monkey from December 2018-March 2019. Results 143/306 (47\%) trainees responded.

Conclusions Our survey demonstrated local good practice examples. Implementation of our recommendations with School Board Support will improve junior doctors' working conditions as outlined by NHS improvement.

\section{G384(P) NO NEWS ISN'T NECESSARILY GOOD NEWS: REGIONAL EXPERIENCE OF EXCEPTION REPORTING BY TRAINEES}

${ }^{1} S$ Steadman, ${ }^{2} \mathrm{D}$ Aguirre, ${ }^{3} \mathrm{D}$ Kenyon- Blair, ${ }^{4} \mathrm{H}$ Cooper, ${ }^{3} \mathrm{M}$ O'Keeffe, ${ }^{5} \mathrm{R}$ Negrine, ${ }^{6} \mathrm{H}$ Goodyear, Paediatric Research Across the Midlands Network. ${ }^{1}$ Community Paediatrics, Birmingham Community Healthcare NHS FT, Birmingham, UK; ${ }^{2}$ Neonates, University Hospitals Birmingham NHS FT, Birmingham, UK; ${ }^{3}$ Community Paediatrics, Coventry and Warwickshire Partnership NHS Trust, Coventry, UK; ${ }^{4}$ General Paediatrics, Worcestershire Acute Hospitals NHS Trust, Worcestershire, UK; ${ }^{5}$ Neonates, Royal Wolverhampton NHS Trust, Wolverhampton, UK; ${ }^{6}$ General Paediatrics, University Hospitals Birmingham NHS FT, UK

\subsection{6/archdischild-2020-rcpch.328}

Aims As part of a wider piece of work looking into the ' 8 High Impact Interventions to Improve the Working Lives of Junior Doctors' document, we gathered data on trainees' experience of how often they worked beyond their scheduled hours, then their experience of the exception reporting systems. The system is designed to allow doctors to report concerns that compromise their safety or training, to allow trusts to remedy the issues in a timely fashion.

Methods A voluntary questionnaire was designed based on the '8 High Impact Actions to Improve the Working Environment for Junior Doctors' document by NHS Improvement. This was circulated on paper at trainees' regional teaching days and online via Survey Monkey from December 2018-March 2019. Results Responses were received from 47\% (143/306) of trainees. $18 \%(124 / 136)$ reported working over their scheduled hours daily, 37\% (50/136) reported working over hours weekly. $88 \%(116 / 132)$ of trainees stated they had never exception reported.

Of the remainder:

- $4 \%(5 / 132)$ reported once

\begin{tabular}{|c|c|c|}
\hline & Emerging themes & Recommendations \\
\hline 1. Tackling work pressures & $\begin{array}{l}\text { Heavy workload, regular tasks that could be done by non-medical practitioners } \\
\text { and documentation duplication. }\end{array}$ & $\begin{array}{l}\text { QI projects to streamline processes e.g. finding procedure consumables. } \\
\text { Encouraging upskilling of non-medical professionals. }\end{array}$ \\
\hline $\begin{array}{l}\text { 2. Rest Breaks and safe travel } \\
\text { home }\end{array}$ & Excessive workload, rota gaps and poor/no rest facilities. & $\begin{array}{l}\text { Sleep advice as part of all trusts' induction programmes. } \\
\text { Changes to travel home arrangements due with } 2019 \text { Junior Doctor } \\
\text { Contract changes. }\end{array}$ \\
\hline 3. Access to food and drink & $\begin{array}{l}\text { Difficult access to catering facilities (time/location) and drink restrictions in some } \\
\text { clinical areas. }\end{array}$ & $\begin{array}{l}\text { Encouraging water fountains/drink stations and promoting a take-your- } \\
\text { breaks culture. }\end{array}$ \\
\hline $\begin{array}{l}4 \& 5 \text {. Engagement between trust } \\
\text { board, managers and trainees }\end{array}$ & $\begin{array}{l}\text { Few opportunities to network or attend meetings due to short rotations and } \\
\text { busy rotas. }\end{array}$ & $\begin{array}{l}\text { Encouraging trainees to participate in paired learning, shadowing } \\
\text { schemes and on-the-job leadership training }\end{array}$ \\
\hline $\begin{array}{l}\text { 6. Rotas promoting work life } \\
\text { balance }\end{array}$ & $\begin{array}{l}\text { Rota gaps, lack of flexibility and trainees working beyond rostered hours; } \\
\text { reluctance to exception report as concern about negative senior responses. }\end{array}$ & $\begin{array}{l}\text { Promote culture of trainee involvement in rota design and exception } \\
\text { reporting. }\end{array}$ \\
\hline 7. Promoting excellence & Trainees greatly value acknowledgement and gratitude for their hard work. & $\begin{array}{l}\text { Continue promoting a positive culture, including more work- based } \\
\text { assessment opportunities, excellence reporting and trust awards. }\end{array}$ \\
\hline $\begin{array}{l}\text { 8. Wellbeing, support and } \\
\text { mentoring }\end{array}$ & Varied amount and knowledge of local and regional support & Designated wellbeing reps, signposting and wellbeing sessions \\
\hline
\end{tabular}

